\begin{tabular}{|c|c|c|c|}
\hline Pts Achieving Response, \% (LOCF) & $\begin{array}{l}\text { PBO } \\
n=84\end{array}$ & $\begin{array}{l}\text { APR } \\
n=83\end{array}$ & $\begin{array}{l}\text { ETN } \\
n=83\end{array}$ \\
\hline \multicolumn{4}{|l|}{ Week 16} \\
\hline PASI-75 & 11.9 & $39.8^{*}$ & $48.2^{*}$ \\
\hline SPGA 0 or $1^{5}$ & 3.6 & $21.7^{\ddagger}$ & $28.9^{*}$ \\
\hline ScPGA 0 or $1^{5}$ & 25.9 & $44.4^{*}$ & $50.0^{\dagger}$ \\
\hline NAPSI- $50^{\text {sf }}$ & 10.9 & $250^{=m}$ & $480^{*}$ \\
\hline Percent change from BL in NAPSIm & -10.1 & -18.7 & -37.7 \\
\hline Week 104 & $\begin{array}{c}\text { PBOIAPR } \\
n=73\end{array}$ & $\begin{array}{c}\text { APRIAPR } \\
n=74\end{array}$ & $\begin{array}{c}\text { ETN/APR } \\
n=79\end{array}$ \\
\hline PASI-75 & 50.7 & 45.9 & 51.9 \\
\hline $\mathrm{SPGA} 0$ or $1^{\mathrm{s}}$ & 27.4 & 18.9 & 26.6 \\
\hline ScPGA 0 or $1^{\mathrm{5}}$ & 50.0 & 59.2 & 56.6 \\
\hline NAPSI-50 55 & 48.6 & 60.4 & 65.2 \\
\hline Percent change from BL in NAPS|ฯ & -48.1 & -48.2 & -51.1 \\
\hline \multicolumn{4}{|c|}{ 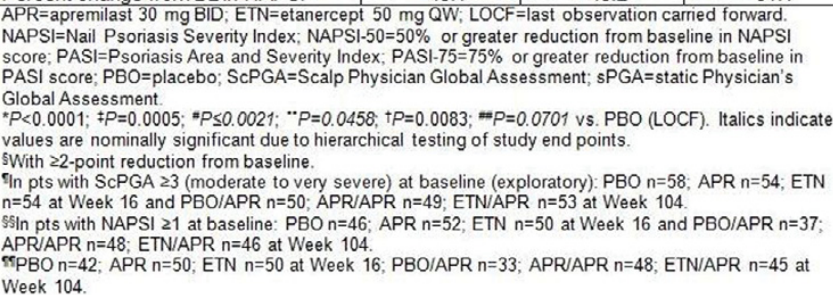 } \\
\hline
\end{tabular}

Disclosure of Interest: K. Reich Consultant for: AbbVie, Amgen, Biogen, Boehringer Ingelheim, Celgene Corporation, Centocor, Covagen, Eli Lilly, Forward Pharma, GlaxoSmithKline, Janssen-Cilag, LEO Pharma, Medac, Merck Sharp \& Dohme, Novartis, Ocean Pharma, Pfizer (Wyeth), Regeneron, Takeda, UCB Pharma, and XenoPort, Speakers bureau: AbbVie, Amgen, Biogen, Boehringer Ingelheim, Celgene Corporation, Centocor, Covagen, Eli Lilly, Forward Pharma, GlaxoSmithKline, Janssen-Cilag, LEO Pharma, Medac, Merck Sharp \& Dohme, Novartis, Ocean Pharma, Pfizer (Wyeth), Regeneron, Takeda, UCB Pharma, and XenoPort, M. Goodfield: None declared, L. Green Consultant for: AbbVie, Amgen, Celgene Corporation, LEO Pharma, Novartis, Pfizer, and Valeant, Speakers bureau: AbbVie, Amgen, Celgene Corporation, LEO Pharma, Novartis, Pfizer, and Valeant, K. Nograles Employee of: Celgene Corporation, R. Chen Employee of: Celgene Corporation, E. Levi Employee of: Celgene Corporation, R. Langley Speakers bureau: AbbVie, Amgen, Celgene Corporation, Eli Lilly, LEO Pharma, Merck, Novartis, and Pfizer

DOI: 10.1136/annrheumdis-2017-eular.5163

\section{AB0772 SECUKINUMAB PROVIDES SUSTAINED IMPROVEMENT IN FUNCTION, QUALITY OF LIFE AND FATIGUE OVER 2 YEARS IN PATIENTS WHO ACHIEVED LOW DISEASE ACTIVITY RELATED TO PSORIATIC ARTHRITIS DISEASE ACTIVITY SCORE (PASDAS)}

L.C. Coates ${ }^{1,2}$, T.K. Kvien ${ }^{3}$, P. Nash ${ }^{4}$, L. Gossec ${ }^{5}$, V. Strand ${ }^{6}$, L. Pricop ${ }^{7}$ L. Rasouliyan ${ }^{8}$, K. $^{2}$ Ding $^{7}$, S. Jugl ${ }^{9}$, C. Gaillez $^{9}$ on behalf of the FUTURE 2 study group. ${ }^{1}$ University of Leeds; ${ }^{2}$ Leeds Teaching Hospitals NHS Trust, Leeds, United Kingdom; ${ }^{3}$ Diakonhjemmet Hospital, Oslo, Norway; ${ }^{4}$ University of Queensland, Brisbane, Australia; ${ }^{5}$ UPMC Université Paris 06, Paris, France; ${ }^{6}$ Stanford University School of Medicine, Palo Alto: ${ }^{7}$ Novartis Pharmaceuticals Corporation, East Hanover, United States; ${ }^{8}$ RTI Health Solutions, Barcelona, Spain; ${ }^{9}$ Novartis Pharma AG, Basel, Switzerland

Background: PASDAS is a composite index measuring disease activity in psoriatic arthritis (PsA), well correlated with $\mathrm{HAQ}$ and health related quality of life $^{1}$.

Objectives: To report the impact of secukinumab on individual core components of PASDAS and its relationship with function (HAQ-DI), health related quality of life (SF36-PCS and MCS, DLQI, PsAQoL) and fatigue in patients (pts) who achieved PASDAS low disease activity (LDA) vs. high disease activity (HDA) through Week (Wk) 104 using post-hoc analysis from FUTURE 2 trial.

Methods: 397 pts with active PsA were randomised to s.c. secukinumab (300, 150 , or $75 \mathrm{mg}$ ) or placebo in FUTURE 2 study. ${ }^{2}$ PASDAS is derived from physician's global VAS, pts global VAS, SF-36 PCS, tender and swollen joints (TJC68 and SJC66), Leeds enthesitis count, dactylitis count and CRP level and has cut-points for HDA $(\geq 5.4)$, LDA $(<3.2)$ and remission (REM $\leq 1.9){ }^{3}$ PASDAS was assessed at Wks 16,52 and 104 and reported as observed using non-mutually exclusive categories at group level. Additionally, the SF-36 PCS, SF-36 MCS, HAQ-DI, FACIT-Fatigue, PsAQoL, and DLQI were assessed by PASDAS LDA and HDA at Wks 16, 52 and 104 using MMRM analyses.

Results: Pts presented similar baseline characteristics. Mean \pm SD score of each PASDAS component among pts reaching LDA and HDA at Wk 16 for each treatment group are shown in table and were similar at Wk 104. Secukinumab treated pts achieving PASDAS LDA had significantly greater improvements in function, physical and mental health quality of life and fatigue compared to HDA through Wk 104 (Figure).

Conclusions: In pts treated with secukinumab, the most improved individual components with PASDAS LDA were related to dactylitis, enthesitis, SF36-PCS, Physician global VAS and SJC at Wk 16 and Wk 104. PASDAS LDA was associated with better improvement in function, quality of life and fatigue than
Table 1. Scores of PASDAS components at Wk 16

\begin{tabular}{|c|c|c|c|}
\hline $\begin{array}{l}\text { Core components, } \\
\text { Mean } \pm \text { SD }\end{array}$ & $\begin{array}{c}\text { Secukinumab/PBO (s.c.), } \\
\mathrm{mg}\end{array}$ & $\begin{array}{c}\text { LDA } \\
\text { 300mg: } \mathrm{n}=37 \\
\text { 150mg: } \mathrm{n}=34 \\
\text { PBO: } \mathrm{n}=14\end{array}$ & $\begin{array}{c}\text { HDA } \\
\text { 300mg: } n=12 ; \\
\text { 150mg: } n=23: \\
\text { PBO: } N=34\end{array}$ \\
\hline \multirow[t]{3}{*}{ Physician/Pt Global VAS } & 300 & $7.3 \pm 7.2 / 14.6 \pm 10.3$ & $43.2 \pm 10.2 / 65.7 \pm 21.6$ \\
\hline & 150 & $8.3 \pm 8.7 / 13.2 \pm 10.3$ & $55.7 \pm 16.2 / 67.8 \pm 14.9$ \\
\hline & PBO & $11.4 \pm 9.8 / 16.7 \pm 13.4$ & $56.7 \pm 12.8 / 64.8 \pm 15.6$ \\
\hline \multirow[t]{3}{*}{ SF-36 PCS } & 300 & $51.5 \pm 5.8$ & $34.9 \pm 6.0$ \\
\hline & 150 & $51.8 \pm 5.5$ & $34.2 \pm 6.5$ \\
\hline & PBO & $49.4 \pm 6.6$ & $33.5 \pm 8.2$ \\
\hline \multirow[t]{3}{*}{ SJC 66/TJC 68} & 300 & $2.2 \pm 3.0 / 2.3 \pm 3.4$ & $12.3 \pm 10.0 / 27.9 \pm 16.1$ \\
\hline & 150 & $1.9 \pm 3.6 / 2.6 \pm 5.0$ & $15.9 \pm 11.1 / 32.3 \pm 21.7$ \\
\hline & PBO & $1.7 \pm 2.0 / 3.4 \pm 4.7$ & $10.1 \pm 6.1 / 25.4 \pm 14.0$ \\
\hline \multirow[t]{3}{*}{ Leeds Enthesitis Score } & 300 & $0.3 \pm 0.8$ & $3.0 \pm 2.5$ \\
\hline & 150 & $0.1 \pm 0.3$ & $3.0 \pm 2.5$ \\
\hline & PBO & $0.2 \pm 0.6$ & $2.4 \pm 1.8$ \\
\hline \multirow[t]{3}{*}{ Tender Dactylitis count } & 300 & $0.03 \pm 0.2$ & $0.9 \pm 2.6$ \\
\hline & 150 & 0 & $1.4 \pm 3.1$ \\
\hline & PBO & $0.1 \pm 0.5$ & $1.3 \pm 2.4$ \\
\hline \multirow[t]{3}{*}{$\mathrm{CRP}(\mathrm{mg} / \mathrm{L})$} & 300 & $3.3 \pm 3.5$ & $5.0 \pm 4.5$ \\
\hline & 150 & $3.3 \pm 3.5$ & $8.1 \pm 11.6$ \\
\hline & PBO & $5.8 \pm 15.2$ & $14.7 \pm 19.5$ \\
\hline
\end{tabular}

Figure: Mean Change in PRO scores by PASDAS states (LDA vs. HDA) at Whs 16, 52 and 104
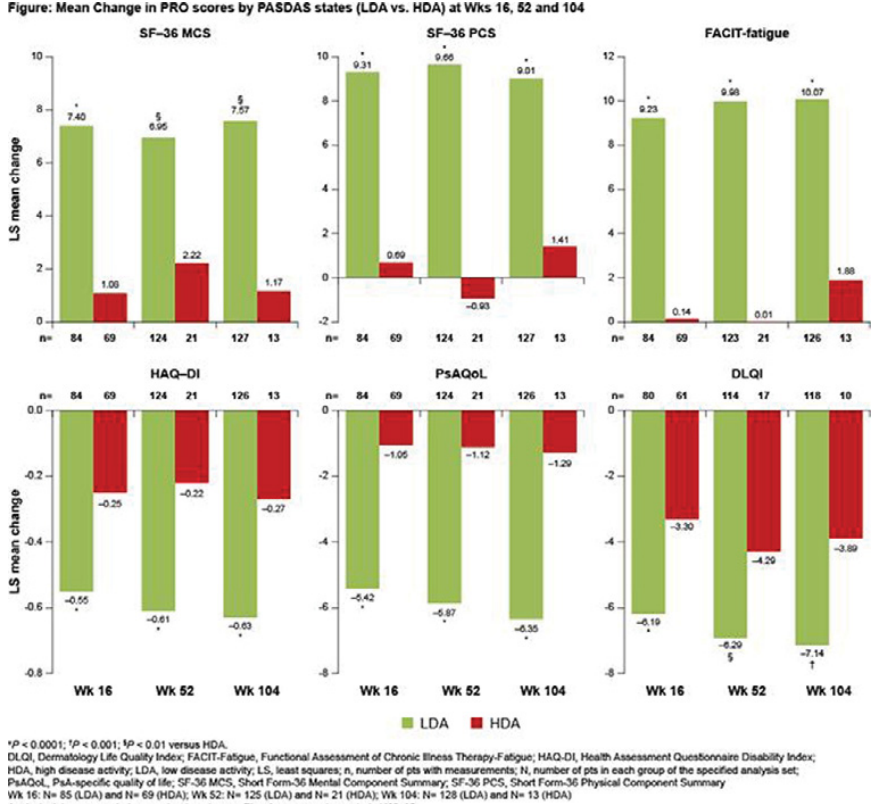

HDA confirming the importance to reach stringent target in a PsA pts with multifaceted disease.

References:

[1] Helliwell PS and Kavanaugh A. Arth Care and Res. 2014;66:749-56.

[2] Mclnnes IB et al. Arthritis Rheumatol.2016;68 (suppl 10).

[3] Coates LC \& Helliwell PS. J Rheumatol. 2016;43:371-5.

Disclosure of Interest: L. Coates Grant/research support from: Abbvie, Janssen, Consultant for: Abbvie, BMS, Celgene, Pfizer, UCB, MSD, Sun Pharma, Novartis, Lilly, Janssen, T. Kvien Consultant for: bbVie, Biogen, BMS, Boehringer Ingelheim, Celltrion, Eli Lilly, Epirus, Janssen, Merck-Serono, MSD, Mundipharma, Novartis, Oktal, Orion Pharma, Hospira/Pfizer, Roche, Sandoz and UCB, Speakers bureau: bbVie, Biogen, BMS, Boehringer Ingelheim, Celltrion, Eli Lilly, Epirus, Janssen, Merck-Serono, MSD, Mundipharma, Novartis, Oktal, Orion Pharma, Hospira/Pfizer, Roche, Sandoz and UCB, P. Nash Grant/research support from: Novartis, Abbvie, Roche, Pfizer, BMS, Janssen, and Celgene, Consultant for: Novartis, Abbvie, Roche, Pfizer, BMS, Janssen, and Celgene, Speakers bureau: Novartis, Abbvie, Roche, Pfizer, BMS, Janssen, and Celgene, L. Gossec Grant/research support from: AbbVie, BMS, Celgene, Janssen, Novartis, MSD, Roche and UCB, V. Strand Consultant for: AbbVie, Amgen, BMS, Celgene, Celltrion, CORRONA, Genentech/Roche, GSK, Janssen, Lilly, Merck, Novartis, Pfizer, Regeneron, Sanofi, and UCB, L. Pricop Shareholder of: Novartis, Employee of: Novartis, L. Rasouliyan Consultant for: Novartis through employment at RTI Health Solutions, Employee of: RTI Health Solutions, K. Ding Shareholder of: Novartis, Employee of: Novartis, S. Jugl Employee of: Novartis, C. Gaillez Shareholder of: Novartis, BMS, Employee of: Novartis

DOI: 10.1136/annrheumdis-2017-eular.1482 